\title{
CHEMOSPHERE
}

\section{Effect of copper in the protistan community of activated sludge}

\author{
Ana Nicolau, Maria João Martins, Manuel Mota, Nelson Lima * \\ Centro de Engenharia Biológica, Universidade do Minho, Campus de Gualtar, 4710-057 Braga, Portugal \\ Received 9 February 2004; received in revised form 29 July 2004; accepted 30 August 2004
}

\begin{abstract}
Protists have proved to be an interesting tool for assessing the occurrence of pollution in wastewater treatment systems along with its role in the control of pollution itself through grazing of dispersed bacteria and maintenance of a healthy trophic web in those artificial ecosystems. Two sets of assays were carried on in a bench scale pilot plant in order to study the response of the activated sludge community of protists to the exposure of copper: the first set was carried on with synthetic sewage and the second one with real sewage. The results emphasize the ability of activated sludge biological communities to survive and to react to toxicants and highlight the role of protistan communities as indicators of toxicants entrance in treatment systems.
\end{abstract}

(c) 2004 Elsevier Ltd. All rights reserved.

Keywords: Protists; Activated sludge; Copper toxicity; Community structure; Sludge biotic index

\section{Introduction}

The presence of toxicants in the aquatic environment has become, in the past years, a problem of common occurrence. Originated mostly by industrial sewage, they reduce the efficiency of wastewater biological treatments due to sludge intoxicant phenomena. Heavy metals are toxic to most microorganisms even at moderate concentrations, but the mechanisms by which they affect the biological systems are not well defined. Though the general response of biological water treatment systems to varying concentrations of heavy metals is well documented (Barth et al., 1965; Yetis and Görkay, 1989; Görkay and Yetis, 1991; Beyenal et al., 1997), only in the last two decades investigators became aware of the importance that these class of pollutants may have in

\footnotetext{
* Corresponding author. Tel.: +351 2536044 00; fax: +351 253678986

E-mail address: nelson@iec.uminho.pt (N. Lima).
}

activated sludge microfauna (Esteban et al., 1990; Battistoni et al., 1993; Madoni et al., 1992, 1994, 1996; Abraham et al., 1997). Different species can present a variable sensitivity to chemicals and, moreover, the sensitivity of a single species can vary from one toxicant to another. This means that a model of action of a set of chemicals found for one species can hardly be applied on another one. However, the toxicity of a chemical or set of chemicals can be demonstrated by testing the whole microfauna community inhabiting the activated sludge in terms of depletion of both organisms and species (Madoni et al., 1996).

The activated sludge treatment process is based in the formation of bacterial aggregates and other associated organisms that may be easily separated from the effluent in sedimentation tanks. Ciliated protists often reach densities of about $10^{7}$ cells per litre in the aeration tank (Madoni, 1993, 1994a) and play an essential role in the purification process by removing, through grazing, the majority of dispersed bacteria, which would cause high turbidity in the final effluent. They are very sensitive to 
environmental variations and, on the other hand, it is recognised that changes in the protistan community may affect the whole food web of those artificial ecosystems, thus affecting the biological performance of the wastewater treatment plants; the structure of the protistan community is therefore an indicator of the operating conditions of the plants (Curds, 1975; Madoni, 1993; Nicolau et al., 1999, 2001).

Most of ciliates present in biological wastewater treatment plants feed, by filtration processes, upon dispersed populations of bacteria and can be divided into three main groups according to their feeding behaviour (Madoni, 1994a): free swimmers, which swim in the sludge liquid fraction and remain in suspension in the sedimentation tank; attached ciliates, which are attached to the bacterial aggregates and settle in the sedimentation tank; and crawlers, which live in the floc surface, and settle in the sedimentation tank as well. A population of organisms associated to the floc has a great advantage comparing to those that swim in the liquid fraction and, thereby, can be washed out of the system. Furthermore, free swimming and attached ciliates are food competitors for the dispersed bacteria while the crawling ciliates, with a "ventral mouth", feed on the lightly adherent bacteria of the floc surface, living in an exclusive ecological niche. In healthy established activated sludge, the latter are, therefore, prevalent.

A true trophic web is established in the aeration tank, including also carnivorous ciliates and metazoa that feed upon filter-feeding ciliates and other protists. Competition, predation and other trophic relations, along with plant management practices, lead to a succession of populations until dynamic stability is reached. In the end, an efficient activated sludge plant should present in the aeration tank (Madoni, 1994a): (1) high microfauna density, at least $10^{6}$ cells per litre; (2) specific composition based in attached and crawling ciliates, with the absence of flagellates which, along with the free-swimming forms, are typical of the colonisation stage; (3) a diversified community, where no group dominates numerically by a factor greater than 10 .

In the present work, an experimental wastewater plant was exposed to several copper concentrations, in order to provide better understanding of the protistan community changes along with the performance of the treatment plant. A first set of assays was carried on with synthetic sewage; the assays were further repeated with real sewage, allowing for the comparison of results.

\section{Materials and methods}

\subsection{Experimental plant}

An experimental prototype of wastewater treatment plants was used having an aeration tank and a sedimen- tation tank (Fig. 1). Table 1 shows the information about several parameters in the experimental prototype.

Two types of feeding were used:

(1) A first set of assays was carried out using synthetic sewage containing sodium acetate $\left(\mathrm{CH}_{3} \mathrm{COONa}\right)$ as the carbon source, ammonium chloride $\left(\mathrm{NH}_{4} \mathrm{Cl}\right)$ as the nitrogen source and potassium di-hydrogen phosphate $\left(\mathrm{KH}_{2} \mathrm{PO}_{4}\right)$ as the phosphorous source. Sources of magnesium, potassium and sulphur were added as well. Micronutrients were supplied by the tap water, which was used after a 48-h resting period, intended to free hypochloride from tap water. In this period, no microbiological growth occurred. The composition of the synthetic sewage was achieved after a series of previous assays in order to find a suitable source of sludge growth, avoiding ordinary problems like excessive fungal growth, foaming and bulking. The measured chemical oxygen demand (COD) of the sewage was about $250 \mathrm{mg} / \mathrm{l}$ and the ratio CODsol/N/P was $100 / 5 / 1$.

(2) A second set of assays used real sewage coming from the Municipal Wastewater Treatment Plant of Braga, after primary treatment, i.e., after the removal of solids, sands and grease and primary sedimentation. Sewage was collected three times a week to prevent self-degradation that could affect the results. The COD of the sewage was between 450 and $500 \mathrm{mg} / \mathrm{l}$ and the ratio CODsol/N/P was approximately $100 / 33 / 4$.

Synthetic sewage and real sewage had both a $\mathrm{pH}$ around 7 and, in the aeration tanks, $\mathrm{pH}$ stood between 5.8 and 6.3 .

The experimental plant was previously inoculated with sludge from the Municipal Plant and a variable period was elapsed until the community was considered stable, as confirmed by assessing the protistan diversity and COD removal. Each assay was accomplished with new "fresh" sludge to ensure the absence of acclimatisation phenomena.

\subsection{Copper concentrations}

Copper, as $\mathrm{CuCl}_{2} \cdot 2 \mathrm{H}_{2} \mathrm{O}$, was used in four concentrations of copper: $4,8,20$ and $50 \mathrm{mg} / \mathrm{l}$, and was added in one single dose to the aeration tank. Considering that only the soluble fraction of heavy metals is toxic to organisms (Madoni et al., 1996), soluble copper was measured in the mixed liquor of the aeration tank just before and 24-h after the adding of the copper chloride solution. The soluble copper concentration was determined, after filtration and digestion with nitric acid $(65 \%)$, by photometric Merck Spectroquant Methods. 


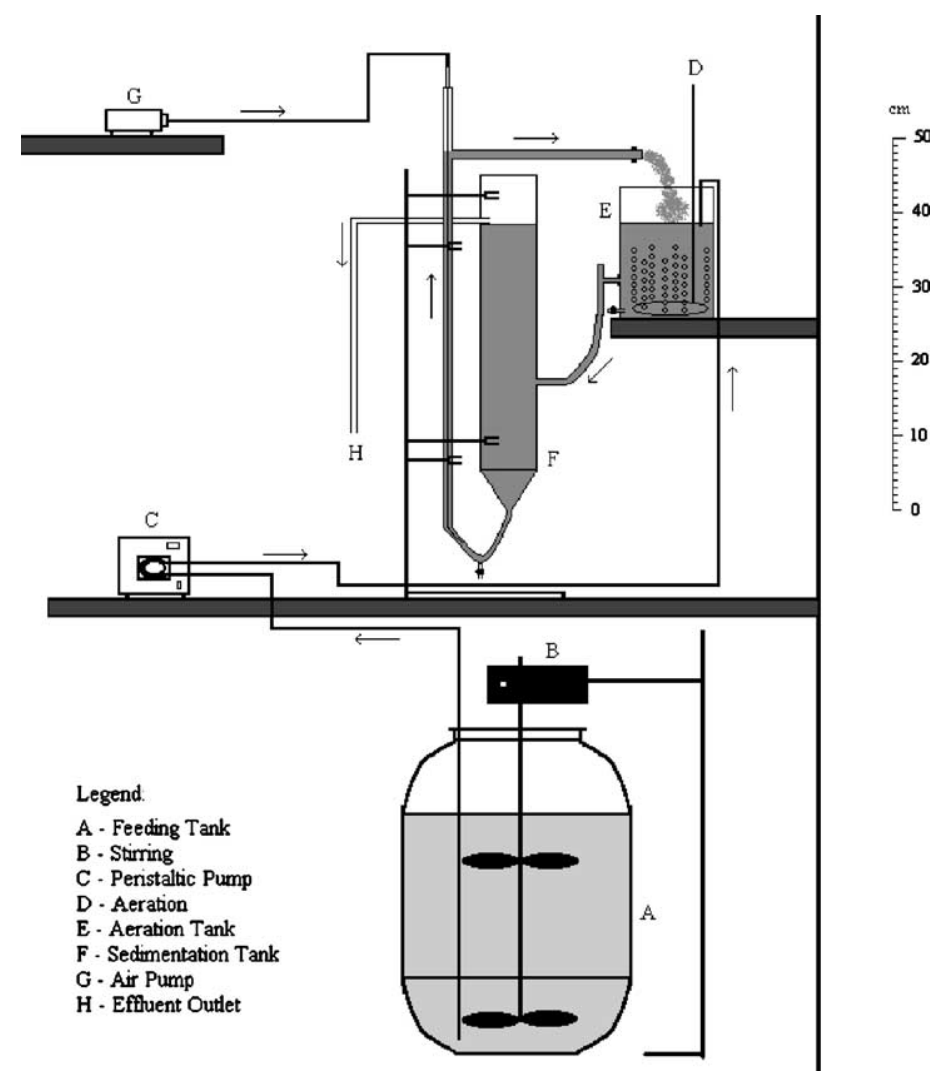

Fig. 1. Experimental prototype of wastewater plant used in the present work.

Table 1

Operational parameters of the bench scale wastewater treatment plant

\begin{tabular}{ll}
\hline Capacity of the aerated tank & 21 \\
Total capacity of the system & 51 \\
Feeding & $3701 / \mathrm{h}$ \\
Residence time in the aerated tank & $5.5 \mathrm{~h}$ \\
Residence time in the system & $13.0 \mathrm{~h}$ \\
Dissolved oxygen in the aerated tank & $3.6-4.8 \mathrm{mg} / 1$ \\
Mean temperature & $19^{\circ} \mathrm{C}$ \\
$\mathrm{pH}$ of the sewage (real and synthetic) & $6.5-7.5$ \\
pH of mixed liquor & $5.8-6.3$ \\
\hline
\end{tabular}

\subsection{Physical-chemical parameters}

During the period of assays, suspended solids (MLSS), volatile suspended solids (MLVSS), temperature $(T)$, dissolved oxygen (DO) and $\mathrm{pH}$ were measured in the aeration tank, following Standard Methods (APHA, 1985), in order to control the operational conditions of both systems. Determinations of COD of the affluent and of the effluent were carried on (using also photometric Merck Spectroquant Methods) to calculate COD removal efficiency.

\subsection{Biological parameters}

Each sample was studied according to the method proposed by Madoni (1994a) and the correspondent functional groups and sludge biotic index (SBI) were achieved. This index is based on the abundance and diversity of the protistan community in the activated sludge of the aeration tank and on the different sensitivity revealed, by some of the microfauna groups, to physical-chemical and operational factors prevailing in the system. SBI may range from 0 , indicating the poorest condition, to 10 , indicating the best condition. SBI values are grouped in four classes corresponding to different levels of quality: class I includes SBI values of 10 , 9 and 8 , class II includes 7 and 6 , group III includes 5 and 4 and class IV includes the remaining values. The numerical evaluation allows for the comparison of different sludges or of sludge biological quality through time, and is based on the relationship occurring between plant performances and operating conditions on one hand, and structure of the microfauna on the other.

To calculate the SBI, it is necessary to find previously the number of species (or supra-specific level whenever species identification cannot be achieved), the 
abundance of each species and of total microfauna and to estimate the number of small flagellates.
Microscopic analysis was performed using bright field and, whenever necessary, phase contrast illumina-

Table 2

Soluble copper in the aeration tank before and after the adding of copper chloride

\begin{tabular}{|c|c|c|c|c|c|}
\hline \multicolumn{2}{|c|}{$\begin{array}{l}\text { Metal initial } \\
\text { concentration }\end{array}$} & \multicolumn{2}{|c|}{$\begin{array}{l}\text { Soluble concentration before metal } \\
\text { inoculation }(\mathrm{mg} / \mathrm{l})\end{array}$} & \multicolumn{2}{|c|}{$\begin{array}{l}\text { Soluble metal increment } 24 \mathrm{~h} \text { after } \\
\text { inoculation }(\mathrm{mg} / \mathrm{l})\end{array}$} \\
\hline $\mathrm{mg} / \mathrm{l}$ & $\mathrm{mM}$ & $\bar{A}$ & B & $\bar{A}$ & B \\
\hline 50.00 & 0.794 & $0.12 \pm 0.03$ & $0.13 \pm 0.02$ & $0.77 \pm 0.10$ & $3.44 \pm 0.13$ \\
\hline 20.00 & 0.317 & $0.12 \pm 0.03$ & $0.11 \pm 0.03$ & $0.28 \pm 0.09$ & $0.58 \pm 0.06$ \\
\hline 8.00 & 0.126 & $0.12 \pm 0.01$ & $0.12 \pm 0.01$ & $0.16 \pm 0.05$ & $0.35 \pm 0.05$ \\
\hline 4.00 & 0.063 & $0.12 \pm 0.04$ & $0.12 \pm 0.04$ & $0.09 \pm 0.03$ & $0.15 \pm 0.05$ \\
\hline
\end{tabular}

(A) Experiment with synthetic sewage; (B) experiment with real sewage. Values presented are the medium of three determinations \pm standard deviation.

(A)
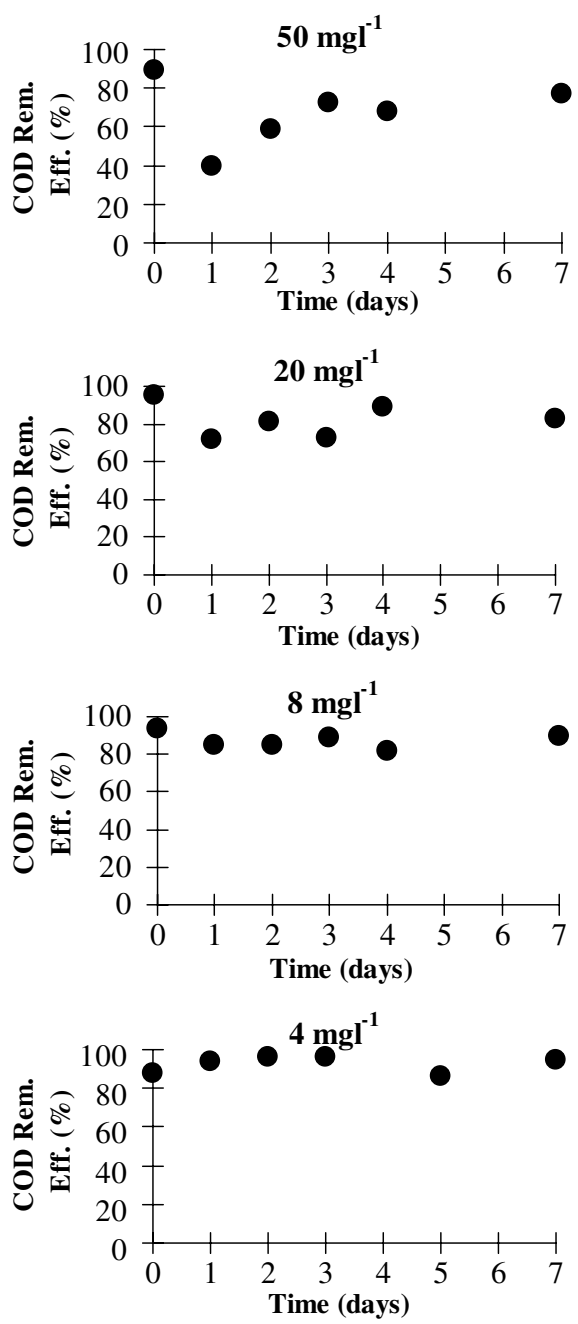

(B)
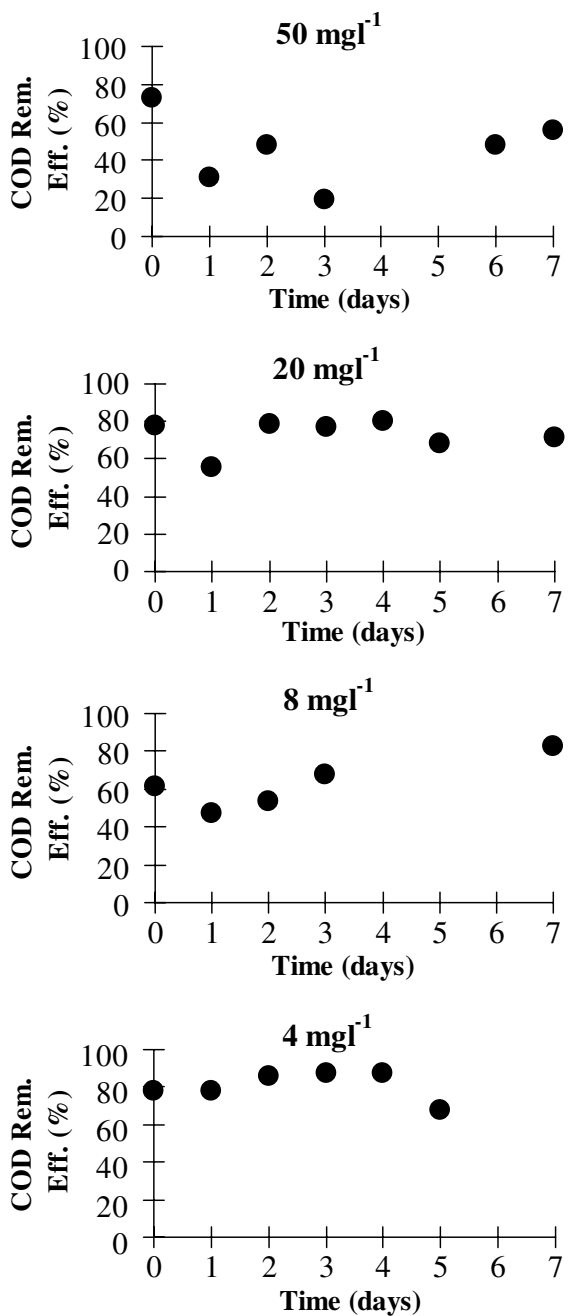

Fig. 2. Effect of copper on the effectiveness of COD removal, using synthetic (A) and real sewage (B). 
tion to inspect two sub-samples of $25 \mu 1$ taken from the aeration tank according to the sub-sampling technique described by Madoni (1984). Protists were identified according to Madoni (1994b) and Foissner et al. (1992).

Almost all assays lasted seven days, but, in two cases, the assays had to be interrupted before due to logistic problems: they took four and six days, in the assays with real sewage, when the concentrations being tested were 50 and $4 \mathrm{mg} / \mathrm{l}$, respectively.

\section{Results}

It is known that organic matter can, in a variable degree, complex cupric ions, making them non-toxicant for aquatic life. The results of the determination of soluble copper after the adding of the copper chloride solution are shown in Table 2. As the results do not reflect in any case these concentrations, and sometimes even contradict them, it was decided not to discuss them in these terms. An explanation to this situation can be the fact that the main effects of copper were inflicted in the 24$\mathrm{h}$ following the addition of the toxicant solution, when an important part of the cupric ions was not yet complexed by organic matter or washed out in the effluent.

The patterns obtained for the variation of MLSS (data not shown) in the experiments were, in a general way, difficult to interpret. The MLSS oscillated a lot during the assays, probably due to design problems, causing sometimes and without explanation, sludge washouts. These oscillations, along with the variation of COD in the effluent led to incomprehensible patterns of variation in other patterns such as organic load, for example. The MLVSS presented the same patterns of variation of MLSS in all assays. The ratio VSS/TSS was always between 0.8 and 0.9 in the experiment with synthetic sewage and 0.7 and 0.9 in the experiments with real sewage.

Among physical-chemical parameters, removal of COD seems to be the only one that presents patterns revealing some coherence along toxicological assays. These are shown in Fig. 2.

High concentrations of copper (50 and $20 \mathrm{mg} / \mathrm{l})$ affected negatively the efficiency of COD removal but, in the case of $50 \mathrm{mg} / \mathrm{l}$, the effects were stronger and lasted more in the assay using real wastewater (Fig. 2B). In the assay with synthetic wastewater, $8 \mathrm{mg} / 1$ of copper had no apparent effect on COD removal efficiency; though a decrease was observed when real efficient was used. It must be pointed out however that the experimental plant and the Municipal Plant were facing some problems in the time of experimentation, apparently caused by the quality of the sewage, which could interfere with the present results. The lowest assayed copper concentration, $4 \mathrm{mg} / \mathrm{l}$, increased slightly the efficiency of COD removal in both cases.
Taxa found in the mixed liquor during the assays are listed in Table 3. The effects of copper on the microfauna, expressed by the sludge biotic index (SBI), generally reflected those results and are shown in Fig. 3. In the assay using synthetic sewage, the microfauna was negatively affected by 50,20 and $8 \mathrm{mg} / 1$ and only $4 \mathrm{mg} / 1 \mathrm{did}$ not significantly alter the value of SBI (Fig. 3A); anyway, after seven days, only the community exposed to $50 \mathrm{mg} / \mathrm{l}$ had not recovered to a value of SBI belonging to the quality class I. In the assay using real sewage, the same concentrations decreased the SBI value and, as in the previous case, by the end of the assay, only the microfauna exposed to $50 \mathrm{mg} / \mathrm{l}$ of copper had not recovered (Fig. 3B). On the other hand, $4 \mathrm{mg} / \mathrm{l}$ of copper affected the SBI value more drastically than in the experiment with synthetic sewage, and SBI values reached the class quality II.

Table 3

Taxa of protists found in the tested mixed liquor during the assays

\begin{tabular}{l}
\hline Crawling ciliates \\
Aspidisca cicada \\
Aspidisca lynceus \\
Chilodonella uncinata \\
Euplotes patella \\
Euplotes affinis \\
Stylonychia $\mathrm{sp}$. \\
Trithigmostoma cucullulus \\
Trochilia minuta
\end{tabular}

Testate amoebae

Arcella sp.

Difflugia sp.

Euglypha sp.

Swimming ciliates

Cinetochilum margaritaceum

Colpidium sp.

Paramecium caudatum

Paramecium putrinum

Spirostomum teres

Uronema nigricans

Sessile ciliates

Carchesium sp.

Epistylis sp.

Opercularia sp.

Vorticella convallaria

Vorticella microstoma

Vorticella aquadulcis

Zoothamnium sp.

Carnivorous forms

Amphileptus sp.

Coleps sp.

Litonotus sp.

Podophrya sp.

Prorodon sp.

Tokophrya sp. 
(A)
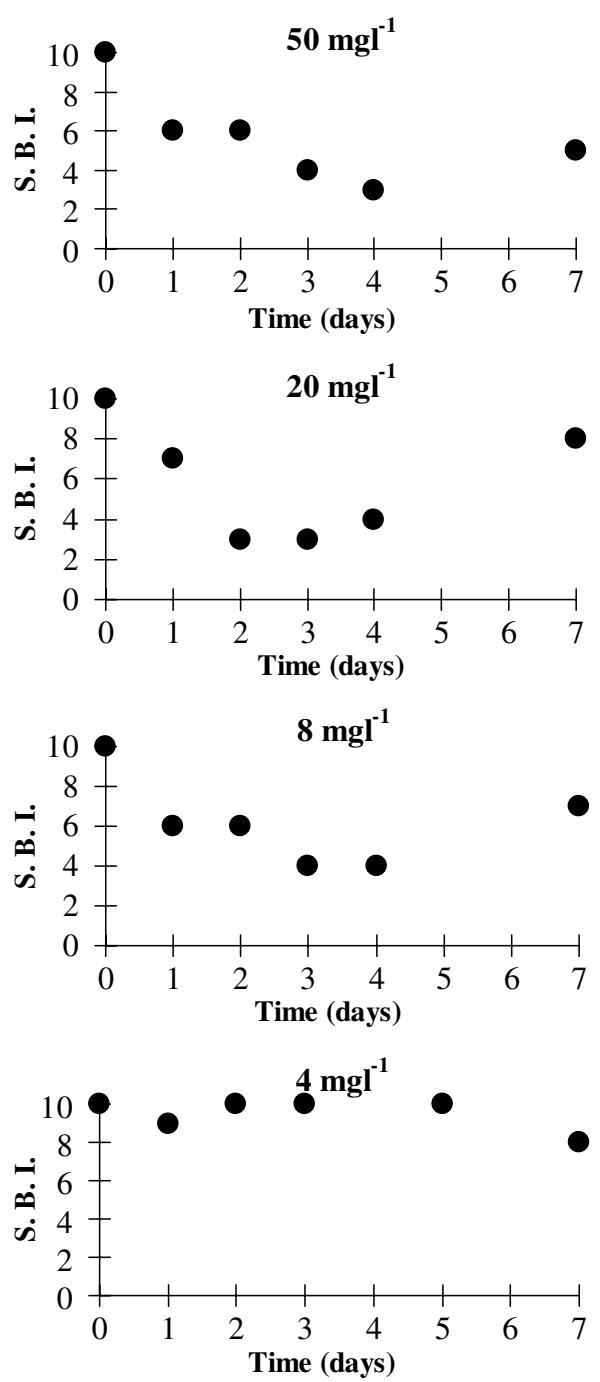

(B)
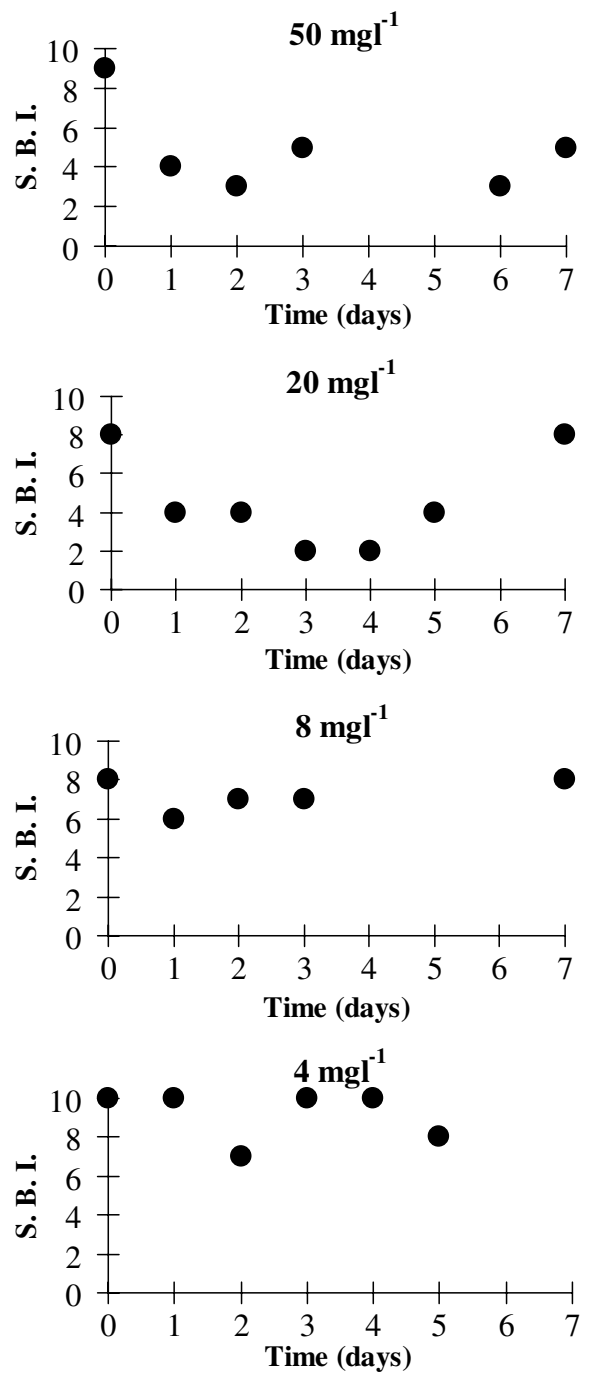

Fig. 3. Effect of copper on the sludge biotic index (SBI), using synthetic (A) and real sewage (B).

Another way of illustrating the effect of copper on the structure of microfauna is patent in Fig. 4, where the variations of the different groups of protists along the seven days after adding copper are expressed in terms of percentage. In the case of synthetic sewage (Fig. 4A), the most remarkable fact was that, seven days after adding copper, the communities exposed to 50 and $20 \mathrm{mg} / \mathrm{l}$ of copper seemed almost recovered; those exposed to the two lowest concentrations were notoriously nonequilibrated, with carnivores species clearly being dominant in the aeration tank. In the case of real sewage (Fig. 4B), the situation was remarkably different: by the end of the assay, the community exposed to $50 \mathrm{mg} / \mathrm{l}$ of copper did not recover the equilibrium, the sessile clearly dominating the aeration tank. When exposed to 20,8 and $4 \mathrm{mg} / \mathrm{l}$ of copper, the community recovered and, by the end of the assays, the communities were diversified with no species or functional group clearly dominating any of the samples.

Fig. 5 shows the expected variation in the structure of the microfauna community when non-toxic synthetic sewage is used, that is, in control conditions. After seven days being fed with synthetic sewage, the community was strongly dominated by carnivores, feeding on other protists: by the end of the control assay, carnivores represented more than $50 \%$ of the individuals present in the aeration tank.

Finally, Fig. 6 shows the variations of Opercularia sp. and crawlers contingents in the activated-sludge of the aeration tank exposed to the four concentrations of cop- 
(A)
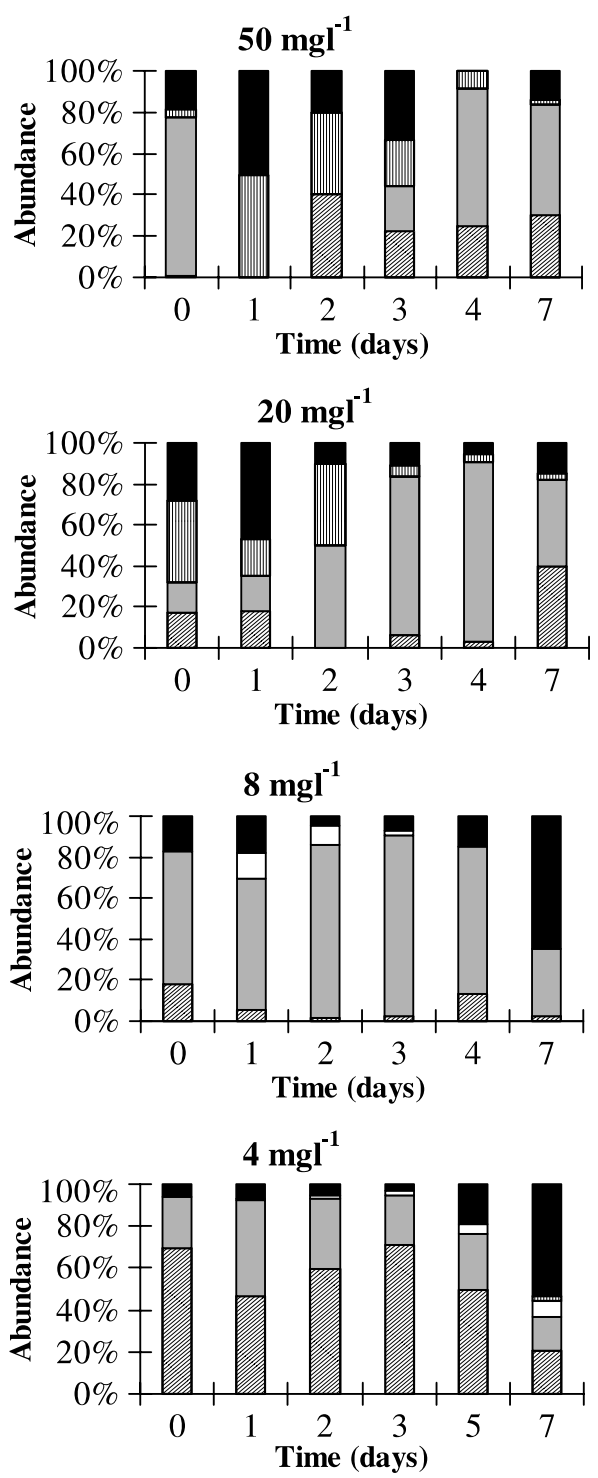

(B)
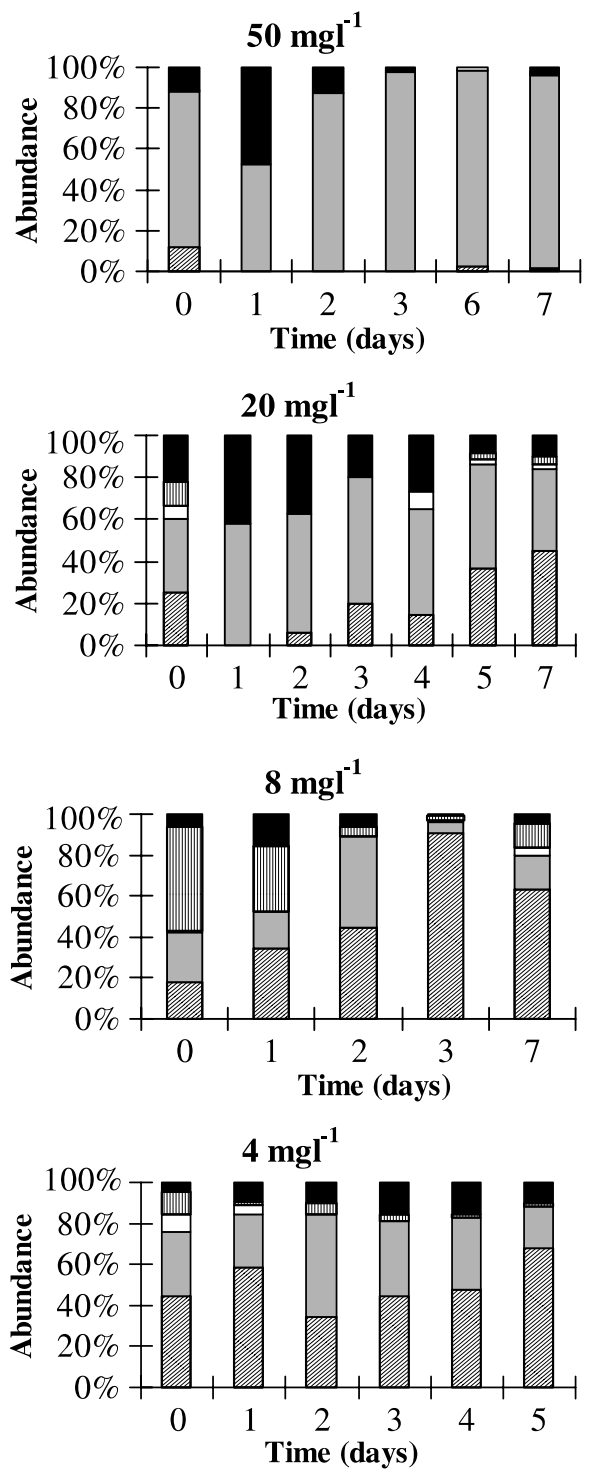

Fig. 4. Effect of copper on the structure of microfauna, using synthetic (A) and real sewage (B). (ロ) Carnivores, (四) Testate amoebae,

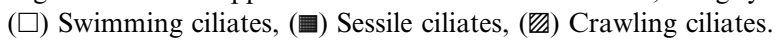

per. In the experiment with synthetic sewage (Fig. 6A), the highest concentration inhibited growth and recovery only began by the fourth day; in the experiment with real effluent (Fig. 6B), a sudden depletion of both groups was observed in the first day, but Opercularia sp. overcame it and clearly dominated the aeration tank thereafter. At a concentration of $20 \mathrm{mg} / \mathrm{l}$ of copper, a similar effect could be observed in the experiment with synthetic effluent, but by the end of the assay, crawlers and Opercularia sp. co-dominated the samples; in the experiment with real sewage, $20 \mathrm{mg} / \mathrm{l}$ of copper caused an initial depletion followed by co-dominance of both groups. With $8 \mathrm{mg} / 1$ of copper, after a blossoming of Opercularia sp. in the fourth day, these organisms decayed to their previous numbers and crawlers at very low densities, in both experiments. The lowest concentration, $4 \mathrm{mg} / \mathrm{l}$ of copper, caused, in the experiment with synthetic sewage, an explosion of crawler species occurred instead and Opercularia sp. contingent did not change much; by the end of the assay, densities of both Opercularia sp. and crawlers were very low. When the influent was real sewage, both groups stood in high densities but, since 


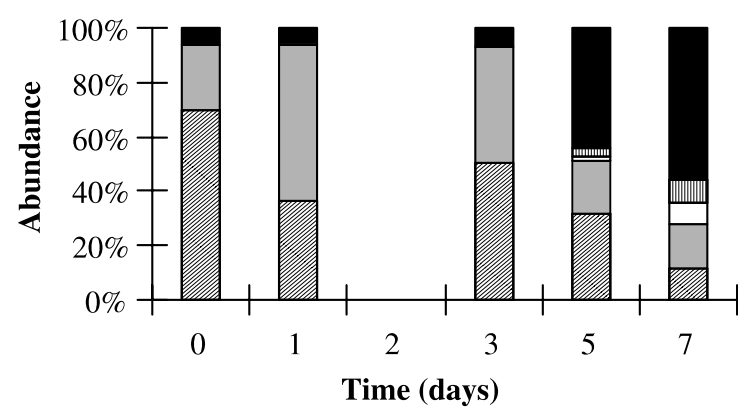

Fig. 5. Variation in the structure of the microfauna when no toxicant is added to synthetic sewage: (ם) Carnivores, (四)

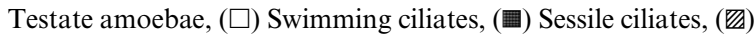
Crawling ciliates.

the third day, crawlers became the dominant group in the aeration tank.

\section{Discussion and conclusions}

In the experiment with synthetic sewage, the situations were clearly determined by the enrichment of carnivores with time; by the end of the assays with 4 and $8 \mathrm{mg} / \mathrm{l}$ of copper, SBI was 7 , belonging to class of quality II and the carnivores clearly dominated the samples. With $20 \mathrm{mg} / \mathrm{l}$ of copper, the SBI was also 7 but the community was dominated by crawlers and sessile, as a healthy established microfauna community should be. The highest concentration, $50 \mathrm{mg} / \mathrm{l}$ of copper, caused a reduction in the community diversity that was not completely recovered by the end of the assay: the number of organisms was low, the sessile Opercularia sp. dominated the aeration tank and SBI only reached 5 . The efficiency of COD removal has in all cases recovered by the seventh day of experiment. So, copper in low concentrations favours the carnivores, perhaps by turning their preys more vulnerable and weak; in high concentrations, both groups are affected, giving sessile and crawlers a chance to recover. It must not be forgotten that carnivores seem to be naturally favoured by the conditions prevailing in this experiment (Fig. 5).

In the experiment with real sewage, by the end of the assay with $50 \mathrm{mg} / \mathrm{l}$, SBI was 5 too, and Opercularia sp. clearly dominated the aeration tank; apart from these sessile ciliates, almost no other species appeared, but total number of individuals was higher than $10^{6}$ per $\mathrm{ml}$; the efficiency of COD removal was still below $60 \%$. With $20 \mathrm{mg} / \mathrm{l}$ of copper, the microfauna community was heavily affected but, by the seventh day the SBI value was 8 , though the total density stood low; Opercularia sp. was relatively abundant but crawler species and testate amoebae too. The two lowest concentrations assayed seemed to stimulate the growth of crawler species, and did not heavily affected neither the microfauna community, nor the efficiency of COD removal, except in the case of $8 \mathrm{mg} / \mathrm{l}$, when it dropped from $60 \%$ to less than $50 \%$; even the first value is low and, as mentioned above, this was probably due to the entrance of toxic sewage. The main problem of this type of feeding seems to be the relative amount of uncontrolled variables coming in with the sewage, meaning that copper was not the only variable factor in the experiment that should be taken in account.

On the other hand, synthetic sewage apparently led to an higher complexation of copper, reducing, in time, its toxicity; in a general way, the MLSS and the relative content of nutrients are scarcer in the experiment with synthetic sewage; in the mixed liquor of this experiment, the dissolved organic matter content is higher, which can explain the lower content of dissolved copper 24-h after the adding.

The consequences of a higher content of nutrients $(\mathrm{N}$ and $\mathrm{P}$ ) in the real sewage are not apparent neither in COD removal nor in the microfauna, probably because the synthetic sewage has the minimum required amounts of nutrients for the decomposers and so, a larger amount is not reflected in the biological parameters.

Despite that, this study allows for the outdrawn of similar conclusions for both experiments:

(1) copper affects not only the efficiency of the activated sludge process, but also the sludge microfauna and both effects can be related, considering the present knowledge about the importance of the microfauna in water treatment processes by activated sludge; the structure of microfauna was affected by changing both species dominance and density;

(2) high concentrations of copper affect heavily the microfauna community, but recovery is likely to occur without any special measures, in the range of concentrations presently tested. Sludge efficiency in removing dissolved organic matter was, as well, affected, but recovered even sooner than the microfauna. This corroborates the idea that both sludge bacteria and protists are able to survive in the presence of heavy metals, namely copper, and the fact highlights the possibility that purification can continue even when additional amounts of copper are entering the system; one must not forget however that heavy metal are likely to bioaccumulate - in sludge in this particular case-and sludge is often used in the amendment of agricultural soils;

(3) low concentrations of copper seem to have a stimulatory effect on removal efficiency of COD and on the growth of some species, namely on some crawling forms. Acineria uncinata and Aspidisca cicada showed, in the present study, a remarkable tolerance to low concentrations of copper, in the assays with synthetic and real 
(A)
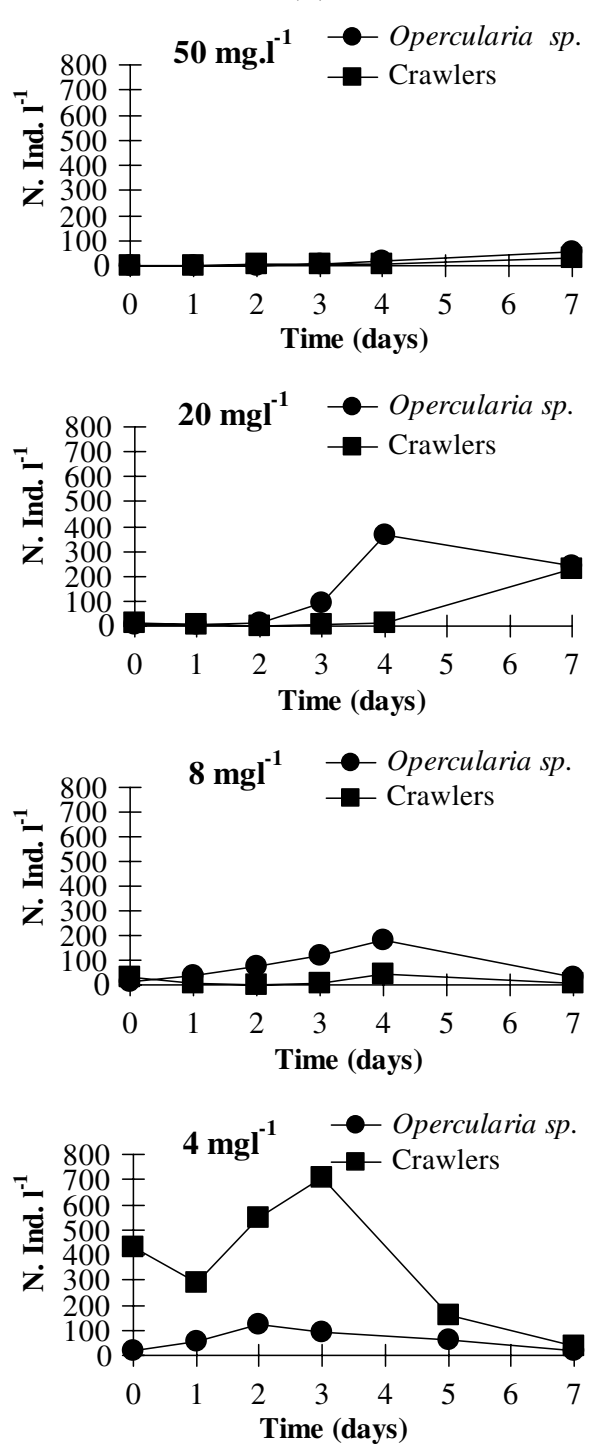

(B)
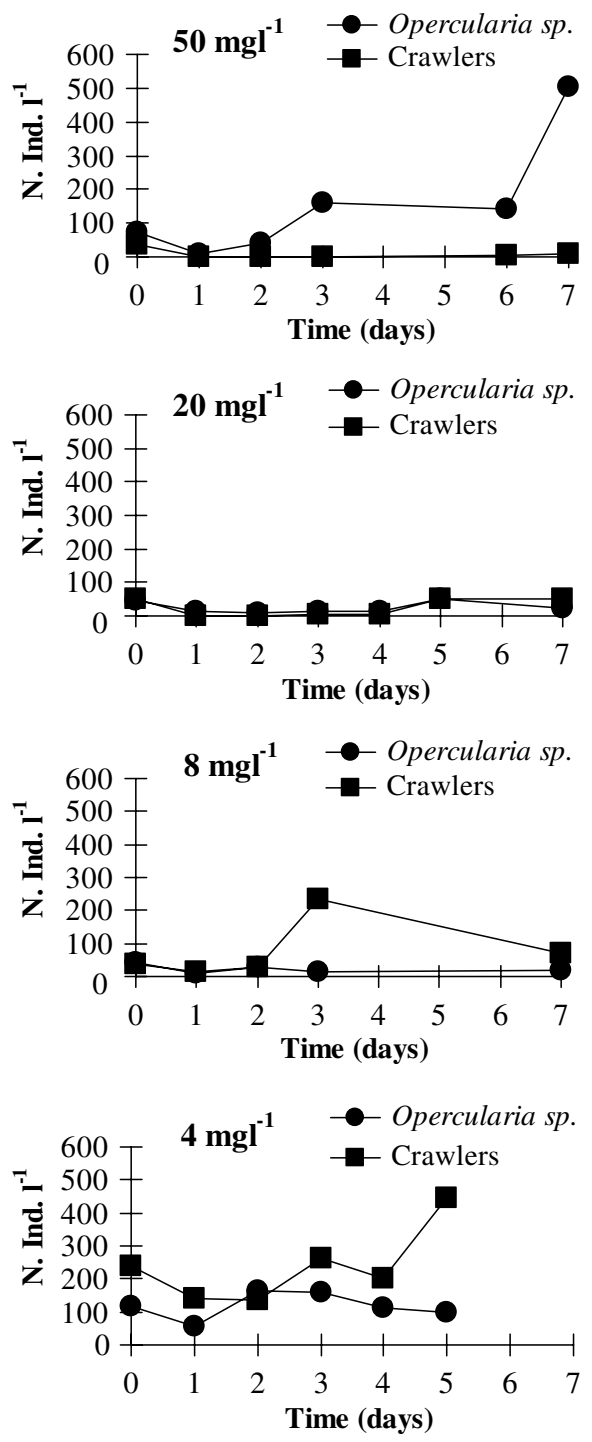

Fig. 6. Effect of copper on the populations of Opercularia sp. and crawling ciliates, using synthetic (A) and real sewage (B).

sewage, respectively (data not shown). Other authors have mentioned the occurrence of Acineria uncinata (Gracia et al., 1994) and Aspidisca cicada (Madoni et al., 1992; Gracia et al., 1994; Abraham et al., 1997) in this situation. Salvadó et al. (1995) refers the same for another crawling ciliate, Euplotes sp. Crawling forms are in general considered useful indicators of good quality of water treatment, but the concept must not be generalised whenever there is the possibility of contamination by heavy metals;

(4) on the other hand, Opercularia sp. seems to be exceptionally tolerant to copper which emphasises the well documented resistance of these species to stressed environmental conditions; these ciliates are particularly frequent in plants receiving industrial waste containing toxic substances (Esteban et al., 1990) and show a close association with bad quality of the activated sludge (Madoni, 1994a);

(5) results were comparable in the two sets of assays, i.e. with synthetic and real sewage, despite the problems brought by the uncontrolled variability of a real sewage and the gradual dominance of carnivores occurring with time when synthetic sewage was supplied. This dominance can be explained by the lack of some nutrients present in traces in real sewage, which might not be found in synthetic sewage; 
(6) the SBI closely reflected the efficiency of the biological treatment, even considering the above limitations: SBI recovery was slower than that of COD removal efficiency in the assays with the highest concentration of copper $(50 \mathrm{mg} / \mathrm{l})$, but this can be easily explained by the higher level of cellular organisation of the microfauna community.

The protistan community in the aeration tank of activated sludge plants remains an innovating and useful tool to control and verify the biological treatment of wastewater. More studies on the subject in order to assess and compare the effects of toxicants on this community will be of great interest and shall turn the protists a better tool in the monitoring of these complex processes.

\section{Acknowledgment}

Ana Nicolau was supported by grant FRH/BPD/ 11594/02 from Fundação para a Ciência e a Tecnologia (FCT), Portugal.

\section{References}

APHA, 1985. Standard Methods for the Examination of Water and Wastewater, 16th ed. APHA, AWWA, WPCF, Washington.

Abraham, J.V., Butler, R.D., Sigee, D.C., 1997. Ciliate populations and metals in an activated-sludge plant. Water Res. 31, 1103-1111.

Barth, E.F., Eltinger, M.G., Salloto, B.V., McDermott, G.N., 1965. Summary report on the effects of heavy metals on the biological treatment process. J. Water Poll. Control Fed. 37, 86-96.

Battistoni, P., Fava, G., Ruello, M.L., 1993. Heavy metal shock load in activated sludge uptake and toxic effects. Water Res. 27, 821-827.

Beyenal, N.Y., Ozbelge (Baser), T.A., Ozbelge, H.O., 1997. Combined effects of $\mathrm{Cu}^{2+}$ and $\mathrm{Zn}^{2+}$ on activated sludge process. Water Res. 31, 699-704.

Curds, C.R., 1975. Protozoa. In: Curds, C.R., Hawkes, H.A. (Eds.), Ecological Aspects of Used Water Treatment. Academic Press, London, pp. 203-268.
Esteban, G., Tellez, C., Bautista, L.M., 1990. Effects of habitat quality on ciliated protozoa communities in sewage treatment plants. Environ. Technol. 12, 381-386.

Foissner, W., Berger, H., Kohman, F., 1992. Taxonomische und ecologische revision der ciliaten des saprobiensystem. Band I-IV. Bayerischeslandesamt für Wasserwirtschaft, München.

Görkay, C.F., Yetis, Ü., 1991. Effect of chromium(IV) on activated sludge. Water Res. 25, 65-73.

Gracia, M.P., Salvadó, H., Rjus, M., Amigó, J.M., 1994. Effects of copper on ciliate communities from activated sludge plants. Acta Protozool. 33, 219-226.

Madoni, P., 1984. Estimation of the size of freshwater ciliate populations by a sub-sampling technique. Hydrobiologia 111, 201-206.

Madoni, P., Esteban, G., Gorbi, G., 1992. Acute toxicity of cadmium, copper, mercury and zinc to ciliates from activated sludge plants. Bull. Environ. Contam. Toxicol. 49, 900-905.

Madoni, P., 1993. Comparative analysis of the activated sludge microfauna in several sewage treatment works. Water Res. 27, 1485-1491.

Madoni, P., 1994a. A sludge biotic index (SBI) for the evaluation of the biological performance of activated sludge plant based on the microfauna analysis. Water Res. 28, 67-75.

Madoni, P., 1994b. La microfauna nell'analisi di qualitá biologica dei fanghi attivi. Azienda Gas Accqua Consorziale di Reggio Emilia, Università degli Studi di Parma, Italy.

Madoni, P., Davoli, D., Gorbi, G., 1994. Acute toxicity of lead, chromium and other heavy metals to ciliates from activated sludge plants. Bull. Environ. Contam. Toxicol. 53, 420-425.

Madoni, P., Davoli, D., Gorbi, G., Vescovi, L., 1996. Toxic effects of heavy metals on the activated sludge protozoan community. Water Res. 30, 135-141.

Nicolau, A., Martins, M.J., Mota, M., Lima, N., 1999. Estudo da Comunidade de Protozoários Exposta a Tóxicos em Estações de Tratamento de Águas Residuais. In: $6^{\mathrm{a}}$ Conferência Nacional sobre a Qualidade do Ambiente, Lisbon, vol. 2. Faculdade de Ciências e Tecnologia da Universidade Nova de Lisboa, Plátano Editora, Lisboa, pp. 659-668.

Nicolau, A., Dias, N., Mota, M., Lima, N., 2001. Trends in the use of protozoa in the assessment of wastewater treatment. Res. Mirobiol. 152, 621-630.

Salvadó, H., Garcia, M.P., Amigó, J.M., 1995. Capability of ciliated protozoa as indicators of effluent quality in activated sludge plants. Water Res. 29, 1041-1050.

Yetis, Ü., Görkay, C.F., 1989. Effect of nickel(II) on activated sludge. Water Res. 23, 1003-1007. 